\title{
Reviewing Legal Justice, Certainty, and Legal Expediency in Government Regulation Number 24 of 2018 Concerning Electronically Integrated Business Services
}

\author{
Raden Mas Try Ananto Djoko Wicaksono \\ Faculty of Law, Universitas Gadjah Mada, Sleman, Yogyakarta, Indonesia \\ Email: tryananto.wicaksono@gmail.com \\ ORCID Link: https://orcid.org/0000-0002-0907-890X
}

\section{Citation:}

Wicaksono, R. M. T. A. D. (2021). Reviewing Legal Justice, Certainty, and Legal Expediency in Government Regulation Number 24 of 2018 Concerning Electronically Integrated Business Services. Lex Scientia Law Review, 5(1), 1-24, doi: https://doi.org/10.15294/lesrev.v5i 1.44905

\section{History of Article}

Received: February 14, 2021

Revised: May 17, 2021

Accepted: May 27, 2021

(C) The Author(s)

\section{(c) (i) 8 (9)}

This work is licensed under a Creative Commons Attribution-NonCommercialShareAlike 4.0 International License. All writings published in this journal are personal views of the authors and do not represent the views of this journal and the author's affiliated institutions.

Lex Scientia Law Review published by Faculty of Law, Universitas Negeri Semarang, Indonesia in collaboration of UKM Lex Scientia. Published biannually every May and November.

\begin{abstract}
This study conducted a legal review of Government Regulation Number 24 of 2018 as the forerunner to the formation of OSS. Aims to analyze the elements of justice, legal certainty and legal expediency in accordance with the objectives of the formation of law. This research is a normative juridical research with the technique of collecting material from the literature consisting of primary and secondary legal materials. The results show that the application and enactment of OSS on the basis of Government Regulation Number 24 of 2018 concerning Electronically Integrated Business Licensing Services is not in accordance with legal objectives. This is due to the absence of a transition period in the enactment of the regulations and provides an opportunity for the community and / or business actors to learn and adapt to a system that is completely new in the world of business licensing.
\end{abstract}

\section{KEYWORDS}

Legal Certainty; Legal Expediency; Legal Justice; Online Single Submission 


\section{INTRODUCTION}

The Government of Indonesia through Government Regulation Number 24 of 2018 concerning Electronic Integrated Business Licensing Services provides convenience for business licensing that is integrated electronically or better known as Online Single Submission (OSS) which is directed at swift and increasing investment and doing business and facilitating business actors, both individuals and non-individuals.

Technically, OSS has the advantage of making it easy to apply for licensing online via the oss.go.id page. This OSS changes the paradigm of licensing in Indonesia, which was previously submitted conventionally by coming to the licensing counter by submitting files, now only with a computer or gadget connected to the internet everyone can easily carry out permits, both individuals and non-individuals (business entities).

The running of OSS in the form of ease of doing business (EODB) has a significant influence in increasing the ranking of licensing ease in Indonesia. ${ }^{1}$ In accordance with data published by the World Bank with the enactment of the OSS indicator of starting a business, Indonesia increased to the 10th place from 144 to $134 .^{2}$ However, after 1 (one) year of OSS, Indonesia's EODB ranking was stuck at 73 . World Bank explained that the reason why Indonesia is stuck in rank 73 is because Indonesia has the most rigid labor regulations compared to other countries, especially with job hiring.

On the other hand, the retention of Indonesia's ranking could be due to the output of the OSS The implementation of PP 24/2018 as a forerunner to the formation of OSS has so far encountered obstacles in its application. ${ }^{3}$ The obstacle that occurs is the absence of a transition period in the implementation of PP 24/2018 where the regulation takes effect immediately after being enacted. In addition, the licensing system at the central level has not been integrated, such as Ministries or Institutions (K / L) with OSS.

In addition, several regions in Indonesia have also implemented an application-based independent licensing system or One Stop Integrated Service (PTSP) which has not been integrated with OSS. This is based on the

${ }^{1}$ Desi Arianing Arrum, 'Kepastian Hukum Dalam Perizinan Berusaha Terintegrasi Secara Elektronik (Online Single Submission) Di Indonesia', Jurist-Diction 2, no. 5 (2019): 1631, https://doi.org/10.20473/jd.v2i5.15222.

2 Rima Wirayani, 'Ease of Doing Business RI Turun, Ini Penjelasan Bank Dunia', CNBC Indonesia, 2018, https://www.cnbcindonesia.com/news/20181031201049-4-40020/ease-of-doing-business-riturun-ini-penjelasan-bank-dunia.

${ }^{3}$ Arif Gunawan, 'Ini Penyebab Peringkat Doing Business Indonesia Mentok Di 73', CNBC Indonesia, 2019, https://www.cnbcindonesia.com/news/20191024225303-4-109976/ini-penyebab-peringkatdoing-business-indonesia-mentok-di-73/1. 
fact that the computer system between $\mathrm{K} / \mathrm{L}$, both at the central and regional levels, is not well connected. The Head of Section (Kasi) of BKPM's Technical Support System, Fitriana Aghita Pratama, argues that there are several problems with OSS implementation, especially at the regional level. He is of the opinion that there are still obstacles in the integration process between OSS and the regional licensing system. The hope is that after the integration process is completed, it is hoped that all licenses will be carried out through OSS. 4

There are problems regarding Norms, Standards, Procedures and Criteria (NSPK). According to Boedi Rheza as a researcher from the Regional Autonomy Implementation Monitoring Commission (KPPOD) explained that the NSPK, which is a technical guideline for licensing services, does not actually translate PP 24/2018. One of them is the case of the NSPK problem when a business actor wants to obtain an industrial business license (IUI). Entrepreneurs first need to register again with the Ministry of Industry's National Industrial Information System (SIINAS) application. Meanwhile, the OSS regulations state that they do not require these requirements. Finally, there were various variations in the SOP for regional permit services, which confounded local governments and business actors. ${ }^{5}$

From the problems above, the author intends to conduct a legal review of PP 24/2018 as the forerunner to the formation of OSS. As for the problems formulated by the author, including whether the application of this OSS has fulfilled the elements of justice, legal certainty and expendiency in accordance with the objectives of the formation of law and is reviewed with related regulations such as the General Principles of Good Governance in accordance with Law Number 25 of 2009 concerning Public Services and Law Number 30 of 2014 concerning Government Administration (Law 30/2014) regarding the application of this OSS.

\section{METHOD}

In this study, the authors analyzed using juridical normative, according to Soekanto and Mamudhi (2003), what is meant by normative research is

\footnotetext{
${ }^{4}$ Mochamad Januar Rizki, 'Dinilai Tak Maksimal, Aturan OSS Perlu Dievaluasi', Hukum Online, 2019, https://www.hukumonline.com/berita/baca/lt5d78d3507a42d/dinilai-tak-maksimal-aturan-ossperlu-dievaluasi/.

${ }^{5}$ Ibid.
} 
research conducted by examining library materials or secondary data. ${ }^{6}$ According to Peter Mahmud Marzuki (2010), normative legal research is a process that aims to obtain a rule of law, legal principles, or legal doctrines that aim to answer a legal issue at hand. ${ }^{7}$ This study intends to present a legal opinion as a determining basis for an event to determine whether suitability is appropriate or not and how should this work according to law. ${ }^{8}$

The technique of collecting material from the library research, includes primary and secondary law materials. ${ }^{9}$ The material from the primary law consists of Government Regulation Number 24 of 2018 concerning Electronically Integrated Business Services. Meanwhile, secondary materials are to assist or support premier legal materials which include books, journals, and other supporting documents. Finally, tertiary legal materials, namely understanding of primary and secondary law such as legal dictionaries, encyclopedias, and others. ${ }^{10}$

\section{RESULT AND DISCUSSION}

In a general review of OSS, following Article 1 Number 5 Government Regulation Number 24 of 2018 concerning Electronically Integrated Business Licensing Services means that, "Electronically Integrated Business Licensing or Online Single Submission, hereinafter abbreviated to OSS, is Business Licensing issued by an Institution. OSS for and on behalf of ministers, heads of institutions, governors, or regents/mayors to Business Actors through an integrated electronic system."

As for what is meant by OSS institutions following Article 1 Number 11 of Government Regulation Number 24 of 2018 concerning Electronically Integrated Business Licensing Services, namely: "OSS Management and Organizing Institutions, hereinafter referred to as OSS Institutions, are nonministerial government institutions that carry out government affairs in the field of coordination capital investment."

The existence of the OSS Institution itself has several powers based on Article 94 Paragraph (1) of the OSS Institution to:

a. issuing Business Licensing through the OSS system;

\footnotetext{
${ }^{6}$ Soerjono Soekanto and Sri Mamudji, Penelitian Hukum Normatif: Suatu Tinjauan Singkat, Raja GrafindoPersada, Jakarta, 2003.

${ }_{7}$ Peter Mahmud Marzuki, Penelitian Hukum Kencana Prenada, Jakarta, 2010.

${ }^{8}$ Mukti Fajar and Yulianto Achmad, Dualisme Penelitian Hukum Normatif \& Empiris, Pustaka Belajar Yogyakarta, 2013.

${ }_{9}^{9}$ Iqbal Hasan, Analisis Data Penelitian Dengan Statistik, Bumi Aksara, Jakarta, 2008.

${ }^{10}$ Saifullah, Konsep Dasar Metode Penelitian Dalam Proposal Skripsi, UIN Malang, Malang, 2004.
} 
b. establish policies for implementing Business Licensing through the OSS system;

c. stipulating the implementation guidelines for the issuance of Business Licensing in the OSS system;

d. managing and developing OSS systems; and

e. cooperate with other parties in the implementation, management, and development of the OSS system.

Basically, this regulation aims to simplify the business permit process, however, the Human Resources (HR) management and office facilities and infrastructure are still less supportive in several regions in Indonesia, especially eastern Indonesia. ${ }^{11}$ Both of these also result in low performance or implementation of OSS services. One of the problems faced is the lack of understanding by business actors on the system, business actors not fulfilling their commitments, and difficulty in internet access. ${ }^{12}$ Thus, the importance of assistance and coordination to resolve obstacles between one institution and another.

\section{A. Legal Justice}

One of the goals of the creation of law is justice. ${ }^{13}$ Justice is a mutual feeling that is related between humans to one another. According to John Rawls (2006) argues about justice related to the principle of freedom, namely, equality or equality for every human being (principle of greatest equal liberty), on this matter John Rawls argues that everyone has the same rights as their respective freedoms. ${ }^{14}$

This statement leads to the opinion of Satjipto Rahardjo (2006) that the relationship between law and justice is two things that cannot be separated, justice is not only limited to discussing something formal but as part of the expression of the ideals of society, in an outline or comprehensive manner. ${ }^{15}$

${ }^{11}$ Inri Monica Priscila Meray, 'Implementasi One Stop Servica (OSS) Dan Pelayanan Perizinan Terpadu (BP2T) Kota Manado', Jurnal Administrasi Publik 1, no. 1 (2014), p. 1-11.

${ }^{12}$ Muhammad Iqbal Fitra Assegaf, Henny Juliani, and Nabiatus Sa'adah, 'Pelaksanaan Online Single Submission (OSS) Dalam Rangka Percepatan Perizinan Berusaha Di Dinas Penanaman Modal Dan Pelayanan Terpadu Satu Pintu (DPMPTSP) Jawa Tengah', Jurnal Hukum Diponegoro 8, no. 2, 2019, p. 1328-42.

${ }^{13}$ Shidarta Dardji Darmohardjo, Pokok-Pokok Filsafat Hukum: Apa Dan Bagaimana Filsafat Hukum Indonesia, Gramedia Pustaka Utama, Jakarta, 2006.

${ }^{14}$ Rawls. John, 'Teori Keadilan: Dasar-Dasar Filsafat Politik Untuk Mewujudkan Kesejahteraan Sosial Dalam Negara', in A Theory of Justice, ed. Uzair Fauzan and Heru Prasetyo, Pustaka Pelajar, Yogyakarta, 2006, p. 502.

${ }^{15}$ Satjipto Rahardjo, Hukum Dalam Jagad Ketertiban, Universitas Diponegoro, Semarang:, 2006. 
Justice is different from equalizing or getting an equal share. ${ }^{16}$ Indonesia as a rule of law should be able to provide justice in terms of public services to every citizen of its country regardless of a particular group or group. This is stated in the Constitution (UUD) of the Republic of Indonesia 1945 in Article 28D paragraph (1) "Everyone has the right to recognition, guarantees, protection and legal certainty that is just and equal treatment before the law."

If you pay attention, to implementing PP 24/2018 which makes OSS make it easier for business actors to manage all their permits, it is very questionable whether this system can be easily reached and used by all Indonesian people. OSS which needs to be accessed using a computer or gadget and connected to the internet makes it difficult for Indonesians who are far from internet coverage and have limitations in their operation. ${ }^{17}$ Even though justice in public services cannot be measured only by how easy and fast the system is, but how to create a system that can reach all levels of society.

\section{Legal Substance}

According to Friedman in Cahyono (2019) legal substance defines as the creation of a legal structure, both regulations made through formal structural mechanisms and regulations that are born from a habit. ${ }^{18}$ Thus, it can be understood that the substance of the law includes applicable laws and regulations which have the power to bind and become a guide for law enforcement officials.

The legal substance contained in managing business licenses at OSS is contained in Article 20 PP 24/2018, in which within 1 (one) day a Business Permit can be issued directly. After the issuance of a business license, business actors cannot just leave their responsibilities. Business permits issued by OSS are a first step towards obtaining a location permit/water location permit, environmental permit, and/or building construction permit (IMB) according to commitments for business actors who need infrastructure in carrying out their business. ${ }^{19}$

\footnotetext{
${ }^{16}$ Shidarta, Moralitas Profesi Hukum Suatu Tawaran Kerangka Berfikir, PT. Revika Aditama, Bandung, 2006.

17 Putri Pradnyawidya Sari, 'Pemanfaatan Teknologi Digital Sebagai Percepatan Berusaha Oleh Ekonomi Kreatif (Utilization of Digital Technology As a Acceleration of Trying By the Creative Economy)', Jurnal Komunikasi, Media Dan Informatika 7, no. 3, 2018, p. 135-44.

${ }^{18}$ H. Cahyono, Model Mediasi Penal Dalam Penanggulangan Konflik Kekerasan, Yogyakarta, 2019.

${ }^{19}$ Article 32 paragraph (2) Government Regulation 24/2018
} 
This commitment is what becomes a "debt" for business actors. Indirectly, with the capital of a Business Permit and/or Environmental Permit and/or IMB to commit to business actors, they can start the construction of their business infrastructure. Even businesses that are located in an area are not required to have an Environmental Permit or an IMB to start development ${ }^{20}$ and only need to prepare a detailed RKL-RPL based on the area's RKL-RPL. ${ }^{21}$ However, business actors must first complete an environmental impact analysis (Amdal) and/or a technical building plan. ${ }^{22}$

Looking at the explanation in the previous paragraph, it can be seen that the PP 24/2018 regulation is more inclined to facilitate business actors with large capital. There are indeed exceptions for Water Location Permits and Environmental Permits for micro, small and medium enterprises (MSMEs), ${ }^{23}$ but in terms of OSS application, not all micro-business actors understand and can carry out business applications in the system. The same thing was expressed by the MSME actor, Alven Stony, where UMKM players sometimes have to prepare additional fees to manage permits at OSS because these MSMEs are technologically illiterate (clueless). ${ }^{24}$

Besides, obstacles to the application for MSMEs in the OSS often arise in the Indonesian Business Field Standard Classification (KBLI) which is out of sync through the data code that is on the AHU Ratification of the Ministry of Law and Human Rights. As a result, the application was submitted immediately rejected. The officer usually recommends returning to the notary to change the deed, which of course costs more for processing the deed. ${ }^{25}$

When compared with Law Number 25 of 2009 concerning Public Services regarding the implementation of this OSS, it is not as expected. Article 3 letter b of Law 25/2009 states "The objective of the law on public services is the creation of a proper public service delivery system following the general principles of good governance and corporate governance." The application of OSS based on this article is indeed feasible, but only for a few people who understand technology. The majority of UMKM actors who do

\footnotetext{
20 Article 35 paragraph (1) and Article 36 Government Regulation 24/2018

${ }^{21}$ Article 35 paragraph (2) Government Regulation 24/2018

${ }^{22}$ Article 38 paragraph (2) Government Regulation 24/2018

${ }^{23}$ Article 34 paragraph d and Article 35 paragraph (1) b Government Regulation 24/2018

${ }^{24}$ Alven Stony, 'Program Afirmasi UMKM, Solusi Bagi Jeritan UMKM', Kompas, 2019,

https://www.kompasiana.com/alvenstony0615/5dacf550097f367d2c413522/program-afirmasi-umkmsolusi-bagi-jeritan-umkm?page=all.

${ }^{25}$ Ibid.
} 
not understand and are clueless about it certainly feel unfair because of this ignorance. Whereas the essence of law is expected to bring fair rules to the community (rapport du droit, inbreng van recht). ${ }^{26}$

\section{Legal Structure}

The legal structure is related to law enforcement institutions, institutional authorities, and personnel (law enforcement officials). ${ }^{27}$ The legal structure itself has a strong influence on elements of legal culture. The legal structure that cannot mobilize the legal system will create disobedience to the law itself. Thus, if the legal structure corrupts the law, it will create a culture of abuse of the law. ${ }^{28}$

Regarding the legal structure according to the subject of the above discussion, PP 24/2018 is a strengthening rule of Presidential Regulation Number 91 of 2017 concerning Acceleration of Business Implementation, which regulates the implementation of the Integrated Electronic Business Licensing System or OSS. ${ }^{29}$ This is similar to the thought of Hans Kelsen who stated that the static presentation of law, the constitution being a higher norm, is projected as part of a lower norm. ${ }^{30}$

OSS as a product of PP 24/2018 regulations will certainly intersect with higher or equivalent regulations, namely laws and/or government regulations in their implementation. In the case of the issuance of an Environmental Permit by OSS as regulated in PP 24/2018, it is certainly a matter of debate in many circles. This is because the issuance of an Environmental Permit by OSS is contradictory to what has been regulated in Government Regulation Number 27 of 2012 concerning Environmental Permits. Environmental Permits in PP 27/2012 can be issued after categorizing and evaluating Amdal and UKL-UPL. ${ }^{31}$ Meanwhile, the Environmental Permit which is issued by OSS can be issued after the existence of a Business Permit even though it is with a commitment status.

Environmental and Forestry Expert, Hariadi Kartodiharjo explained that the existence of PP 24/2018 actually weakens the position of Amdal and becomes not strategic which so far has played a role as a decision-maker. He also added that PP 24/2018 contradicts Law Number 32 of 2009 concerning

\footnotetext{
${ }^{26}$ Theo Huijbers, Filsafat Hukum, Kanisius, Sleman, 1995.

${ }^{27}$ Lawrence M. Friedman, Hukum Amerika: Sebuah Pengantar, ed. Wisnu Basuki, Tatanusa, Jakarta, 2001

${ }^{28}$ Lutfil Ansori, 'Reformasi Penegakan Hukum Perspektif Hukum Progresif', Jurnal Yuridis 4, no. 2, 2018, Hlm. 148, https://doi.org/10.35586/.v4i2.244.

${ }^{29}$ Article 2 paragraph (1) letter b number 2 Presidential Decree No. 91 of 2017

30 Jimly Asshiddiqie and Ali Safa'at, Teori Hans Kelsen Tentang Hukum, Sekretariat Jenderal \& Kepaniteraan MK RI, Jakarta, 2006.

${ }^{31}$ Article 2 paragraph (2) Government Regulation 27/2012
} 
Environmental Protection and Management (UU PPLH) which strengthens the position of Amdal ${ }^{32}$.

The same thing was expressed by the National Executive Director of Walhi Nur Hidayati, assessing that PP No.24 of 2018 "crashed" many regulations, one of which was the PPLH Law. According to him, the government must pay attention to the environment before issuing policies because ecological disasters and environmental damage continue to increase. Amdal and environmental permits must be the main requirements that must be met before the government issues licenses for business actors. ${ }^{33} \mathrm{He}$ also added that Amdal and environmental permits should not be just a formality but must be the main requirements.

Suharto assessed that the formation of the law was to protect humans either passively or actively. Passively means that it is carried out by making an effort to prevent attempts to abuse rights or arbitrary attitudes aimed at a person or group of people. However, actively means making an effort to create a humane and just social situation. Likewise, in the formation and application of PP 24/2018, the community cannot be excluded, such as the adagium ubi societas ibi ius (where there is a community there is a law). ${ }^{34}$

\section{Legal Culture}

Legal culture is a social mindset and social power that determines how the law is used, avoided, or abused. ${ }^{35}$ In fact, the issuance and enactment of PP $24 / 2018$, creates a new activity throughout society which will then make culture in business activities. However, this application seems to be enforced when the regulation is promulgated..$^{36}$

The absence of a transition period to a new legal system can cause "shock" in the law itself. Activities that have previously been formed and run in such a way then change rapidly without massive socialization and without allowing the public / business actors to prepare anything related to a license. The "surprise" also occurred during 1 (one) month of the OSS implementation.

\footnotetext{
32 PERKHAPPI, 'PP OSS Dinilai Lemahkan Posisi Wajib AMDA', 2019,

https://www.perkhappi.or.id/berita-dan-kegiatan/pp-oss-dinilai-lemahkan-posisi-wajib-amdal/.

${ }^{33}$ Rizki Febianto, 'Anggap Kebijakan Ngawur, Aktivis Lingkungan Gugat PP OSS', Alinea, 2019, https://www.alinea.id/nasional/anggap-kebijakan-ngawur-aktivis-lingkungan-gugat-pp-oss-

b1Xm19mZO.

${ }^{34}$ Muhtarom, 'Pengaruh Budaya Hukum Terhadap Kepatuhan Hukum Dalam Masyarakat', SUHUF 27, no. 2 , 2015, Pg. 124-25.

${ }^{35}$ Satjipto Rahardjo, 'Etika, Budaya, Dan Hukum', Jurnal Hukum \& Pembangunan 16, no. 6 (1986): 54956, https://doi.org/10.21143/jhp.vol16.no6.1229.

${ }^{36}$ Article 107 Government Regulation 24/2018
} 
OSS, which was originally under the control of the Ministry of Economy, opened the OSS Lounge in one of the Ministry of Economy Buildings, which was crowded with business players. The large number of business actors who come to consult and revise data for input errors in OSS makes employees in these places overwhelmed. Before the limitation on queue numbers up to 300 , the consultation could arrive at $23.00 \mathrm{WIB} .{ }^{37}$

There was even a business actor who had consulted 6 (six) times because his business license was withheld as a result of the lack of integration between OSS and K / L. ${ }^{38}$ This legal "shock" event caused chaos to occur in society. This chaos is the responsibility of the government in the future, which must restore or restore order to society and business actors in doing business in Indonesia, such as the principle of restitution in integrum.

\section{B. Legal Certainty}

Legal certainty is the probability that a certain situation is available, one of which is clear, consistent, accessible, issued, and recognized legal rules. ${ }^{39}$ On the other hand, legal certainty is understood as rules whose general meaning becomes a direction for individuals when behaving in society, both in relationships with fellow individuals and concerning society. This regulation will also create legal certainty. This clarity and decisiveness indicate that there is something that is certain and cannot be multiinterpreted. ${ }^{40}$

Legal certainty is actually contained in Article 28D paragraph (1) of the 1945 Constitution as mentioned in the previous discussion, where every citizen has the right to legal certainty and equal treatment before the law. However, the reality on the ground is that there are often overlapping legal rules that cause uncertainty about a legal norm. In recent years, legal uncertainty has often occurred in the business licensing sector, to be precise after the enactment of PP 24/2018 with OSS.

\section{Legal Substance}

OSS as the implementation of PP 24/2018 is predicted to facilitate business licensing practices among the public and investors. Easy access and application of business is an advantage of this system. However, the licensing product produced from OSS is still a matter of debate among observers

\footnotetext{
${ }^{37}$ Rinaldi Mohammad Azka, 'Usahaku Tertahan Perizinan', Bisnis Indonesia, 2018, https://koran.bisnis.com/read/20180814/433/827566/1-bulan-online-single-submission-usahakutertahan-perizinan.

38 Ibid.

${ }^{39}$ Soeroso, Pengantar Ilmu Hukum, Sinar Grafika, Jakarta:, 2011.

${ }^{40}$ Peter Mahmud Marzuki, Pengantar Ilmu Hukum (Jakarta: Kencana, 2008).
} 
because it is considered to have overstepped a checklist procedure that should have been fulfilled before the issuance of a permit. Indeed, an agreement must first fulfill a specified requirement, but in PP 24/2018 it is inversely proportional to where the permit is first granted then there is a commitment which is a statement of business actors to fulfill the requirements of a Business Permit and/or Commercial or Operational License. ${ }^{41}$

Based on this commitment, business actors indirectly have debts to the government. Article 40 PP 24/2018 states that the Business Permit granted by OSS can be canceled simply if the business actor has not been able to complete the fulfillment of the commitment as referred to in Article $32^{42}$ and/or the Commercial or Operational License as referred to in Article 39.43 In fulfilling the commitment, the Business actors are given an average of 10 (ten) to 30 (thirty) days to complete their commitments by reporting to the related institutions or agencies. Let's just say that the fulfillment of the commitments in preparing the EIA document is given a maximum period of 30 (thirty) working days from the time OSS issued the Environmental Permit. ${ }^{44}$

Even though it is contained in Article 30 paragraph (3) Government Regulation 27 of 1999 concerning Environmental Impact Analysis (PP 27/1999) 30 (thirty) working days is a period of time for members of the community who have an interest in or are affected by an attempt to provide or propose suggestions, opinions, and comments regarding the implementation of the business plan and/or activity. Previously, there was an assessment of the EIA reference frame by the responsible agency by no later than 75 (seventy-five) working days. ${ }^{45}$ Thereafter, agencies are given no later than 75 (seventy-five) working days from the receipt of documents for environmental impact analysis, environmental management plans and environmental monitoring

\footnotetext{
${ }^{41}$ Article 1 number 10 Government Regulations 24/2018

42 (1) OSS Institution issues Business License based on Commitment to: a. Business actors who do not need infrastructure to run a business and / or activity as referred to in Article 31 paragraph (2) letter $a$; and $b$. Business actors requiring infrastructure to run a business and / or activity and already owning or controlling the infrastructure as referred to in Article 31 paragraph (3) letter a.

(2) OSS Institutions issue Business Permits based on Commitments to Business Owners who need infrastructure to run a business and / or activities but do not yet own or control the infrastructure as referred to in Article 31 paragraph (3) letter $b$, after the OSS Institution issues: $a$. Location permit; $b$. Water Location Permit; c. Environmental Permit; and / or d. IMB, based on Commitments.

${ }^{43}$ OSS Institutions issue Commercial or Operational Licenses based on Commitment to fulfill:

a. standards, certificates and/or licenses; and/or;

b. registration of goods/services, in accordance with the types of products and/or services commercialized by business actors through OSS.
}

${ }^{44}$ Article 42 paragraph (1) Government Regulation 24/2018

${ }^{45}$ Article 16 paragraph (2) Government Regulation 27/1999

LeSRev (Lex Scientia Law Review) 
plans to issue a decision on the environmental feasibility of a business or activity. ${ }^{46}$

If the accumulated time from the initial preparation of the medal reference frame to the decision on whether or not a business activity is appropriate, it could be more than 180 days or 9 (nine) months. Meanwhile, the time given by PP 24/2018 to complete the commitment is 30 (thirty) working days, which is a very short time and there is a risk of irregularities in the Amdal results which are inaccurate and will have an impact on the community environment. This lack of clarity is a problem in implementing OSS. The overlap and the absence of synchronization of regulations with one another cause the absence of legal certainty, illustrating that no law regulates it (ubi jus incertum, ibi jus nullum).

Meanwhile, if you look at Utrecht's opinion that legal certainty includes two understandings, namely: (1) the existence of rules that are general in nature makes individuals know what actions are allowed or not to be done; and (2) in the form of legal security for individuals from government arbitrariness due to general rules, individuals can know what the state may impose or do against individuals. ${ }^{47}$ This means that the OSS problem regarding legal uncertainty shows that there is no legal security for every citizen due to the government's arbitrariness in implementing regulations.

\section{Legal Structure}

The legal structure as a context for a consistent form of the legal system to oversee the process remains within its boundaries. Concerning PP 24/2018 that is a guideline for the application of OSS, it can be said that it is part of Law 25/2009 which is the highest regulation that regulates the provision of public services. The aims and objectives of Law 25/2009, namely, to provide legal certainty for the relationship between the community and administrators in public services. 48

OSS which is classified as a public service provider and part of the government requires providing legal certainty to the public in carrying out administrative services, especially business licensing. ${ }^{49}$ Administrative services performed by OSS also require that an administrative action be based on the prevailing laws and regulations..$^{50}$

Administrative services as an administrative act are also regulated by Law 30 of 2014 concerning Government Administration (Law 20/2014) as

\footnotetext{
${ }^{46}$ Article 20 paragraph (1) Government Regulation 27/1999

${ }^{47}$ Syahrani, Rangkuman Intisari Ilmu Hukum. Op. Cit. p. 23

48 Article 2 Law 25/2009

${ }^{49}$ Article 3 letter d, Law 25/2009

${ }^{50}$ Article 5 paragraph (7), Law 25/2009
} 
regulated in Article 1 number 8 which explains that government administrative actions are actions of Government Officials or other state administrators for those who carry out and/or not taking concrete actions in the framework of running the government.

OSS as a system managed by the Investment Coordinating Board (BKPM) which has the authority to grant business permits to every business actor should be guided by the laws that govern the issued permits, such as AMDAL based on PP 27/1999 and Environmental Permits guided by Law Number 32 the Year 2009 regarding Environmental Protection and Management or its implementing regulations PP 27/2012. This is reaffirmed in Article 39 paragraph (1) and (2) of Law 30/2014 as follows:

(1) Authorized Government Officials can issue Permits, Dispensations, and/or Concessions based on AUPB and based on the provisions of statutory regulations.

(2) Decisions of Government Agencies and/or Officials in the form of Permits if:

a. issued approval before the activity is carried out; and

b. activities to be carried out constitute activities that require special attention and/or comply with statutory provisions.

Looking at the description above, it can be concluded that to guarantee legal certainty, it must be based on legal norms that have been regulated and applicable. However, in implementing OSS and/or PP 24/2018 as a form of public service, there are still legal norms that deviate from the regulations that specifically regulate public services and government administration (permits). Besides, PP 24/2018 as a rule for implementing public services should be guided by Law 25/2009 and Law 20/2014. If you look at the opening of PP 24/2018 in terms of "Considering" and "Considering" there are no two laws, in fact, there is only Law 25 of 2007 concerning Investment and Law Number 9 of 2015 concerning the Second Amendment to Law No. 23 of 2014 concerning Regional Government.

The formation of PP 24/2018 indeed aims to facilitate investment or business and its integration between the central and regional systems. However, on the other hand, PP 24/2018 is also classified as a regulation that regulates how the licensing process runs which ultimately ends in public services and produces a legal permit product that is classified as government administration. The absence of Law 25/2009 and UU 20/2014 in the preamble as the basis for drafting PP 24/2018 can be said that in the drafting of the 
implementing regulation overriding the principle of lex specialis derogate legi generalis which can affect legal certainty for legal products issued by OSS.

\section{Legal Culture}

Changes in people's habits will certainly occur after the enactment of PP 24/2018. The conventional culture that comes to a place with a photocopy of the requirements and a letter of application is an old way that 5 (five) to 10 (ten) years later will be lost. Meanwhile, OSS, as one of the ideals in realizing a new culture that is paperless and easy, still experiences obstacles that sometimes make it difficult for users to obtain legal certainty.

Constraints or obstacles must occur in every change of habits in society. Forming a healthy legal culture is considered the most difficult because it requires a relatively long period of time. This can occur due to culture related to values. So, what is related to values, definitely requires an internalization process so that these values are not only understood but also practiced in everyday life. ${ }^{51}$

According to Soerjono Soekanto's opinion, there are four stages in society to be able to have good legal awareness, namely: (1) legal knowledge; (2) understanding of the law; (3) legal attitude; and (4) legal behavior patterns. ${ }^{52}$ The implementation of OSS is one way to change people's habits in practicing healthy law. This is contrary to the principle of het recht hinkt achter de feiten aan where the law always lags behind its consequences. The old practice which in practice made the law appear to be "bought" causes the loss of legal certainty for the law itself. The public's misunderstanding of the law is also an indicator of the rampant "buying and selling" carried out by authorized persons. Therefore, with the issuance and enforcement of the OSS, it is hoped that the public will be able to understand and understand a legal process in a healthy and direct manner

\section{Legal Expediency}

According to Sudikno Mertokusumo, what is meant by legal benefit is that after considering the principle, the validity (rechmatigheid) of the action, then the benefits (doelmatigheid) are considered. ${ }^{53}$ On the other hand, Jeremy Bentham explained that the correct law is if it can provide happiness for the majority of the society where the law is. The value of benefits found in individuals who give birth to individual happiness and society. The purpose

\footnotetext{
${ }^{51}$ Dardji Darmohardjo, Pokok-Pokok Filsafat Hukum: Apa Dan Bagaimana Filsafat Hukum Indonesia. Loc.Cit.

${ }^{52}$ Soerjono Soekanto, Kesadaran Hukum Dan Kepatuhan Hukum, Rajawali Press, Jakarta, 1982, p. 140.

${ }^{53}$ Sudikno Mertokusumo, Teori Hukum, 1st ed., Universitas Atma Jaya, Yogyakarta, 2011.
} 
of the law itself is expected to provide as much benefit and happiness to the community as possible and the means to achieve a predetermined goal. ${ }^{54}$ Based on the theory of expediency, the memorandum of understanding and agreement contained in the Presidential Regulation not only provides convenience but provides benefits in making decisions and provides added value to the transactions made.

\section{Legal Substance}

OSS as a public service system should provide benefits to all users. The implementation of commitment in issuing a business license is one of the benefits that can be felt by business actors. Due to a business license, business actors can take care of other operational licenses in parallel or simultaneously while fulfilling the requirements for fulfilling said business license commitments. ${ }^{5}$

In the context of implementing the issuance of a business license with a commitment apart from being regulated in Article 32 PP 24/2018, it is also regulated in Perpres 91/2017, one of which is in Article 23 paragraph (3) where business actors can receive a license by simply filling in and signing the application form as a form of fulfillment of requirements (checklist) with the obligations and timeframe for completing the requirements that must be fulfilled.

The benefits of OSS for business actors are indeed felt because it is implemented with an electronic-based system, online and reduces conventional old practices that risk the occurrence of "transactions" by bureaucrats outside the prevailing laws and regulations. Business actors should be happy with the existence of OSS which makes it easy for everything in licensing to issue business licenses with a capital of commitment "debt".

However, to carry out construction, business actors within 90 days of applying/registering must start the construction process ${ }^{56}$ and are required to complete "debt" requirements such as Environmental Management Efforts and Environmental Monitoring Efforts (UKL-UPL), land certificates, IMB,

\footnotetext{
${ }^{54}$ Jeremy Bentham, An Introduction to the Principles of Morals and Legislation, Batoche Books, Kitchener: 2000.

${ }^{55}$ Suhartoyo Suhartoyo, 'Implementasi Fungsi Pelayanan Publik Dalam Pelayanan Terpadu Satu

Pintu (PTSP)', Administrative Law and Governance Journal 2, no. 1 (2019): 143-54,

https://doi.org/10.14710/alj.v2i1.143-154.
}

${ }^{56}$ Article 25 paragraph (7) of Presidential Decree 91/2017

LeSRev (Lex Scientia Law Review) 
Industrial Business Permit or Tourism Business Registration Certificate as stipulated in Article 7 paragraph (2) letter an of Presidential Decree 91/2017.

If the business actor is unable to settle the commitment "debt" within the stipulated time and has not started the construction process either, the Central PTSP, Provincial or Regency / City DPMPTSP have the authority to issue a written warning, give a business license suspension, provide an extension of time to meet the missing requirements. Fulfilled, suspend activities temporarily, and/or revoke temporary business licenses based on commitments. ${ }^{57}$ This means that if the business license is revoked, the business actor cannot continue his business even though the process of fulfilling his commitment is halfway through.

This should indeed be done by the state against business actors who cannot fulfill their promises or pay their "debts" to protect and to provide security the citizens of the citizens who are affected by the business and also protect the state from the arbitrariness of parties. certain rules that violate legal norms. ${ }^{58}$ This is in line with the concept of "law is a tool of social engineering" expressed by Roscoe Pound, where the law is the most important institution in the implementation of social control..$^{59}$ According to him, social control is needed to preserve civilization because of its main function in controlling "the internal aspect of human nature" which he deems indispensable to conquer the external aspect of the physical environment. ${ }^{60}$

\section{Legal Structure}

The existence of Perpres 91/2017 is an advantage in implementing OSS in Indonesia. Hierarchically, the legal strength of the Perpres is under laws or government regulations, but in the formation of the OSS regulation, this Perpres can be said to have initiated the enactment of PP 24/2018. Unfortunately, the drafting of PP 24/2018 did not pay attention to laws relating to public services or matters relating to government administration. Whereas OSS can be said to be a public service system that produces government administration products and has positive or negative legal consequences for its users.

\footnotetext{
${ }^{57}$ Article 24 paragraph (8) of Presidential Decree 91/2017

${ }^{58}$ Zainab Ompu Jainah, Kapita Selekta Hukum Pidana, ed. Intan Nurina Seftiniara (Tangerang: Tira Smart, 2010).

${ }^{59}$ Martha Safira, 'Law as a Tool of Social Engineering', Kodifikasia Jurnal Penelitian Islam 11, no. 1 (2017), https://doi.org/10.2991/icsse-17.2018.28.

${ }^{60}$ Lili Rasjidi and Ira Thania Rasjidi, Dasar-Dasar Filsafat Dan Teori Hukum, Citra Aditya Bakti, Bandung: 2007, p. 74.
} 
If you look at the hierarchy of the promulgation of PP 24/2018, in the future there can be legal uncertainty which leads to the lack of usefulness of laws because they intersect and are not in line with related laws and regulations that specifically regulate certain matters/permits. Meanwhile, to achieve the benefits felt by the citizens, in legislation there is at least a common (to attain equity) perception between the interrelated regulations.

Unsustainability can also occur in a single body of regulations, for example, Article 24 paragraph (7) of Presidential Decree 91/2017 which states "... construction is carried out no later than 90 (ninety days) since being registered as referred to in paragraph (4)" indirectly the perpetrator businesses must complete the commitments contained in paragraph (4) such as UKL-UPL, IMB, etc. within 90 (ninety) days. Meanwhile, in paragraph (11) regarding fulfillment of commitment requirements, it is carried out following the provisions of laws and regulations. If what is meant by the statutory provisions of the respective permit regulations in paragraph (2) letter $a^{, 61}$ if the accumulated time required can be more than 90 (ninety) days.

For this reason, benefits can not only be seen from the happiness felt by the community but also there must be continuity between one regulation and another which are interrelated. This must be the basis for the formation of statutory regulations to create legal certainty which of course affects the satisfaction and happiness of the citizenry of a legal rule.

\section{Legal Culture}

Culture will appear present or seen when getting action from outside, thus culture is a social reaction and response. However, not all cultures are born naturally, there are external forces that can give birth to or change cultures, one of which is the law. ${ }^{62}$ According to the theory of utilitarianism, what is meant by the existence of law is a view that places benefit as the main goal of law and as for the measure of legal usefulness, namely happiness for the people as much as possible. ${ }^{63}$

\footnotetext{
${ }^{61}$ Paragraph (2) letter a of Presidential Decree 91/2017 stated that “... permits for construction and commercial purposes, covering at least: 1. Environmental Management Efforts and Environmental Monitoring Efforts (UKL-UPL); 2. land certificate; 3. Building technical / building construction permit (IMB); and 4. Industrial Business License (IUI) or Tourism Business Registration Certificate (TDUP)"

${ }^{62}$ Satjipto Rahardjo, Hukum Dan Masyarakat, Alumni, Bandung:, 1980.

63 Darji Darmodihardjo, 'Filsafat Hukum', in Filsafat Hukum Edisi Lengkap (Dari Klasik Sampai Postmoderenisme) Rajawali Press, Jakarta, 1990, p. 111.
} 
The application of OSS in the field of public services indirectly changes the long-established habits of the community by photocopying and bringing required documents to the relevant agencies to obtain licensing products. The implementation of OSS has not been fully successful because not all citizens can use it. As an electronic-based system and having to connect to the internet to access it, not all people can and understand how to make requests, even for areas far from the reach of the internet and are forced to disobey the law.

However, with the existence of OSS, the government has tried to provide protection (to provide security) to the citizens of its citizens by changing the old school situation (in the past) which is full of bureaucratic "games" into a public service that is monitored and operated automatically based on the system. Seeing the benefits of the OSS system, there must be a lot of improvement and increased accuracy in the system, but if the OSS system is perfect, the benefits will be seen with how the law shapes modern civilization such as the principle of law is a tool of social engineering where the law is social control in forming a new civilization or culture in society.

\section{CONCLUSION}

Based on the explanation and analysis above, it can conclude that the implementation and enactment of OSS based on Government Regulation Number 24 of 2019 concerning Electronically Integrated Business Licensing Services are not following legal purposes. This is due to the absence of a transition period in the enactment of the regulations and provides an opportunity for the community and/or business actors to learn and adapt to a system that is completely new in the world of business licensing. Besides, there is an overlap between one regulation and another which causes legal uncertainty which then affects the usefulness of the law itself. Thus, the implementation of OSS or PP 24/2018 is not following legal objectives. The need of conduct a judicial review and/or the DPR-RI as a legislative body amends/changes to Government Regulation Number 24 of 2018 concerning Electronically Integrated Business Licensing Services because there are many overlaps with regulations that specifically regulate it so that it does not there is legal certainty that affects the business climate in Indonesia. 


\section{DECLARATION OF CONFLICTING INTERESTS}

None

\section{FUNDING INFORMATION}

None

\section{ACKNOWLEDGEMENT}

I would like to express my deep gratitude to both of my parents, my mother Das Gustina Hilda and my father Alm. Djoko Sadmoko P., for their patient guidance, enthusiastic, and encouragement. My grateful thanks are also extended to both of my sisters, Mba Rini and Mba Rina. Also both of my brothers in law, Kak Rhesa and Kak Yanuar for their support and encouragement throughout my study. Finally, I would also like to thank all my friends, for all the advice, useful critiques of this research work, and assistance.

\section{REFERENCES}

Ansori, Lutfil. (2018). Reformasi Penegakan Hukum Perspektif Hukum

Progresif. Jurnal Yuridis 4, no. 2, 148. https://doi.org/10.35586/.v4i2.244.

Apeldoorn, L.j Van. (2006). Moralitas Profesi Hukum Suatu Tawaran Kerangka Berfikir. Bandung: Revika Aditama.

Arrum, Desi Arianing. (2019) .'Kepastian Hukum Dalam Perizinan Berusaha Terintegrasi Secara Elektronik (Online Single Submission) Di $\begin{array}{lllll}\text { Indonesia'. Jurist-Diction } & 2, & \text { no. } & \text { 5: }\end{array}$ https://doi.org/10.20473/jd.v2i5.15222.

Assegaf, Muhammad Iqbal Fitra, Henny Juliani, and Nabiatus Sa'adah. (2019).'Pelaksanaan Online Single Submission (OSS) Dalam Rangka Percepatan Perizinan Berusaha Di Dinas Penanaman Modal Dan Pelayanan Terpadu Satu Pintu (DPMPTSP) Jawa Tengah'. Jurnal Hukum Diponegoro 8, no. 2, 1328-42.

Asshiddiqie, Jimly, and Ali Safa'at. (2006). Teori Hans Kelsen Tentang Hukum. Jakarta: Sekretariat Jenderal \& Kepaniteraan MK RI.

Atmosudirjo, Prajudi. (2001). Hukum Administrasi Negara. Jakarta: Ghalia Indonesia,.

Azka, Rinaldi Mohammad. 'Usahaku Tertahan Perizinan'. Bisnis Indonesia, 2018. https://koran.bisnis.com/read/20180814/433/827566/1-bulanonline-single-submission-usahaku-tertahan-perizinan.

Bentham, Jeremy. (2000). An Introduction to the Principles of Morals and 
Legislation. Kitchener: Batoche Books.

Cahyono, H. (2019). Model Mediasi Penal Dalam Penanggulangan Konflik Kekerasan. Yogyakarta.

Dardji Darmohardjo, Shidarta. (2006). Pokok-Pokok Filsafat Hukum: Apa Dan Bagaimana Filsafat Hukum Indonesia. Jakarta: Gramedia Pustaka Utama.

Darmodihardjo, Darji. (2011). Filsafat Hukum: Dari Klasik Sampai Postmodernisme. Yogyakarta: Universitas Atma Jaya.

. (1990 ). 'Filsafat Hukum' In Filsafat Hukum Edisi Lengkap (Dari Klasik Sampai Postmoderenisme). Jakarta: Rajawali Press.

Fajar, Mukti, and Yulianto Achmad. (2013). Dualisme Penelitian Hukum Normatif \& Empiris. Yogyakarta: Pustaka Belajar.

Febianto, Rizki. 'Anggap Kebijakan Ngawur, Aktivis Lingkungan Gugat PP OSS'. Alinea, 2019. https://www.alinea.id/nasional/anggap-kebijakanngawur-aktivis-lingkungan-gugat-pp-oss-b1Xm19mZO.

Friedman, Lawrence M. (2001). Hukum Amerika: Sebuah Pengantar. Edited by Wisnu Basuki. Jakarta: Tatanusa.

Gunawan, Arif. (2019). 'Ini Penyebab Peringkat Doing Business Indonesia Mentok Di 73'. CNBC Indonesia. https://www.cnbcindonesia.com/news/20191024225303-4-109976/inipenyebab-peringkat-doing-business-indonesia-mentok-di-73/1.Hasan, Iqbal. Analisis Data Penelitian Dengan Statistik. Jakarta: Bumi Aksara, 2008.

Huijbers, Theo. (1995)Filsafat Hukum. Sleman: Kanisius.

Ismansyah. (2010). Permasalah Hukum Dalam Pengembangan Ilmu Hukum Di Indonesia (Pentingnya Reformasi Hukum Terkait Dengan Permasalahan Hukum). Jurnal Demokrasi 9, no. 1.

Jainah, Zainab Ompu. (2010). Kapita Selekta Hukum Pidana. Edited by Intan Nurina Seftiniara. Tangerang: Tira Smart,.

John, Rawls. (2006 ). Teori Keadilan: Dasar-Dasar Filsafat Politik Untuk Mewujudkan Kesejahteraan Sosial Dalam Negara. In A Theory of Justice, edited by Uzair Fauzan and Heru Prasetyo, 502. Yogyakarta: Pustaka Pelajar,.

Popper, Karl R. (2002). Masyarakat Terbuka Dan Musuh-Musuhnya (The Open Society and Its Enemy). Yogyakarta: Pustaka Pelajar.

Marzuki, Peter Mahmud. (2002) Penelitian Hukum. Jakarta: Kencana Prenada. . (2008). Pengantar Ilmu Hukum. Jakarta: Kencana.

Meray, Inri Monica Priscila. (2014). Implementasi One Stop Servica (OSS) Dan Pelayanan Perizinan Terpadu (BP2T) Kota Manado. Jurnal 
Administrasi Publik 1, no. 1, 1-11.

Mertokusumo, Sudikno. (2011). Teori Hukum. 1st ed. Yogyakarta: Universitas Atma Jaya.

Muhtarom. (2015). Pengaruh Budaya Hukum Terhadap Kepatuhan Hukum Dalam Masyarakat. SUHUF 27, no. 2, 124-25.

PERKHAPPI. 'PP OSS Dinilai Lemahkan Posisi Wajib AMDA', 2019. https://www.perkhappi.or.id/berita-dan-kegiatan/pp-oss-dinilailemahkan-posisi-wajib-amdal/.

Rahardjo, Satjipto. (2006). Hukum Dalam Jagad Ketertiban. Semarang: Universitas Diponegoro. . (1980). Hukum Dan Masyarakat. Bandung: Alumni.

Rahardjo, Satjipto. (1986).Etika, Budaya, Dan Hukum. Jurnal Hukum \& Pembangunan 16, no. 549-56. https://doi.org/10.21143/jhp.vol16.no6.1229.

Rasjidi, Lili, and Ira Thania Rasjidi. (2007). Dasar-Dasar Filsafat Dan Teori Hukum. Bandung: Citra Aditya Bakti.

Rizki, Mochamad Januar. 'Dinilai Tak Maksimal, Aturan OSS Perlu Dievaluasi'. Hukum Online, 2019. https://www.hukumonline.com/berita/baca/lt5d78d3507a42d/dinilaitak-maksimal-aturan-oss-perlu-dievaluasi/.

Republik Indonesia. (2012) Peraturan Pemerintah Nomor 27 Tahun 2012 tentang Izin Lingkungan.

Republik Indonesia. (2018) Peraturan Pemerintah Nomor 24 Tahun 2018 tentang Pelayanan Perizinan Berusaha Terintegrasi Secara Elektronik

Republik Indonesia. (2017) Peraturan Presiden Nomor 91 Tahun 2017 tentang Percepatan Pelaksanaan Berusaha

Republik Indonesia. (2009) Undang-Undang Nomor 25 Tahun 2009 tentang Pelayanan Publik.

Republik Indonesia. (2009) Undang-Undang Nomor 32 Tahun 2009 tentang Perlindungan dan Pengelolaan Lingkungan Hidup.

Republik Indonesia. (2014) Undang-Undang Nomor 30 Tahun 2014 tentang Administrasi Pemerintahan.

Safira, Martha. (2017). 'Law as a Tool of Social Engineering'. Kodifikasia Jurnal Penelitian Islam 11, no. 1. https://doi.org/10.2991/icsse-17.2018.28.

Saifullah. (2004). Konsep Dasar Metode Penelitian Dalam Proposal Skripsi. Malang: UIN Malang.

Sari, Putri Pradnyawidya. (2018) . Pemanfaatan Teknologi Digital Sebagai 
Percepatan Berusaha Oleh Ekonomi Kreatif (Utilization of Digital Technology As a Acceleration of Trying By the Creative Economy). Jurnal Komunikasi, Media Dan Informatika 7, no. 3, 135-44.

Shidarta. (2006). Moralitas Profesi Hukum Suatu Tawaran Kerangka Berfikir. Bandung: PT. Revika Aditama.

Soekanto, Soerjono. (1982). Kesadaran Hukum Dan Kepatuhan Hukum. Jakarta: Rajawali Press.

Soekanto, Soerjono, and Sri Mamudji. (2003). Penelitian Hukum Normatif: Suatu Tinjauan Singkat. Jakarta: Raja Grafindo Persada.

Soeroso. (2011). Pengantar Ilmu Hukum. Jakarta: Sinar Grafika.

Stony, Alven. 'Program Afirmasi UMKM, Solusi Bagi Jeritan UMKM'. Kompas, 2019.

https://www.kompasiana.com/alvenstony0615/5dacf550097f367d2c4135 22/program-afirmasi-umkm-solusi-bagi-jeritan-umkm?page=all.

Suhartoyo, Suhartoyo. 'Implementasi Fungsi Pelayanan Publik Dalam Pelayanan Terpadu Satu Pintu (PTSP)'. Administrative Law and Governance Journal 2, no. 1 (2019): 143-54. https://doi.org/10.14710/alj.v2i1.143-154.

Sulardi. (2015). Kepastian Hukum, Kemanfaatan, Dan Keadilan Terhadap Perkara Pidana Anak. Jurnal Yudisial 9, no. 3, 259.

Suted, Adrian. (2017). Hukum Perizinan Dalam Sektor Pelayanan Publik. 1st ed. Jakarta: Sinar Grafika.

Syahrani, Riduan. (1999). Rangkuman Intisari Ilmu Hukum. Bandung: Citra Aditya,.

Wijayanta, Tata. (2014). Asas Kepastian Hukum, Keadilan Dan Kemanfaatan Dalam Kaitannya Dengan Putusan Kepailitan Pengadilan Niaga. Jurnal Dinamika Hukum 14, no. 2, 219.

Wirayani, Prima. 'Ease of Doing Business RI Turun, Ini Penjelasan Bank Dunia'. CNBC Indonesia, 2018. https://www.cnbcindonesia.com/news/20181031201049-4-40020/ease-ofdoing-business-ri-turun-ini-penjelasan-bank-dunia. 


\section{ABOUT AUTHOR(S)}

Raden Mas Try Ananto Djoko Wicaksono, is a student of a master's degree in business law, Gadjah Mada University and a master's degree in government and public policy, the School of Government and Public Policy in Indonesia. He is interested in international political economy, international economic law, and international relations. Currently, he works as a Government Consultant based in Jakarta. 


\section{LEGAL ADAGE}

\section{JUSTITIAE NO EST NEGANDA, NON DIFFERENDA}

\section{Justice Cannot be Denied or Delayed}

